\title{
Multicomponent Analysis of Amino Acid Transport in Human Lymphocytes \\ Diminished L-System Transport in Chronic Leukemic B Lymphocytes
}

George B. Segel, William Simon, and Marshall A. Lichtman

Departments of Pediatrics, Medicine, and Radiation Biology and Biophysics, University of Rochester School of Medicine, Rochester, New York 14642

bstract. We have examined the amino acid transport in B cell chronic lymphocytic leukemia and compared it with the amino acid transport in isolated B lymphocytes from human blood and tonsils. L-system transport was measured with 2-amino-2-carboxy-bicyclo $(2,2,1)$-heptane, which is a synthetic amino acid whose transport is limited to the L-system. Amino acid uptake was subjected to a multicomponent analysis that partitioned the total uptake into the saturable carrier-mediated transport system and the uptake by diffusion. The maximal velocity of L-system transport in chronic lymphocytic leukemia cells, $81 \mu \mathrm{mol} / \mathrm{l}$ cell water per min, was $<10 \%$ that of blood B lymphocytes, which was $1,029 \mu \mathrm{mol} / \mathrm{l}$ cell water per min. The uptake of 2-amino-2-carboxybicyclo $(2,2,1)$-heptane by tonsillar B cells, by a B lymphocyte cell line, and by blood T-lymphocytes was also 10-fold greater than that observed in chronic lymphocytic leukemic cells. Similarly, the L-system uptake of leucine and phenylalanine, which are naturally occurring amino acids usually transported primarily by the L-system, was reduced in chronic lymphocytic leukemic B cells to 15 and $10 \%$ of normal $B$ cells, respectively. Total leucine uptake by chronic lymphocytic leukemic cells, however, was sustained at $30 \%$ of that expected because of transport via an alternative transport system. The A- or ASC-systems, the other major amino acid transport pathways, were not defective in chronic lymphocytic leukemic cells. These data indicate that there is a specific, profound de-

Address correspondence to Dr. Segel at the University of Rochester Medical Center, Rochester, NY 14642. 1984.

Received for publication 20 July 1983 and in revised form 4 January

J. Clin. Invest.

(c) The American Society for Clinical Investigation, Inc.

0021-9738/84/07/0017/08 \$1.00

Volume 74, July 1984, 17-24 crease in L-system carrier-mediated amino acid transport in chronic lymphocytic leukemic B cells, as judged by the system-specific synthetic amino acid, 2-amino-2-carboxy-bicyclo $(2,2,1)$-heptane. This defect was confirmed by studies with two naturally occurring L-system amino acids, leucine and phenylalanine. This specific abnormality of membrane transport by chronic lymphocytic leukemic B lymphocytes is not shared by other B lymphocyte types, and thus appears to be related to the neoplastic nature of the leukemic B cells rather than to their immunologic subtype.

\section{Introduction}

The membrane of B lymphocytes in chronic lymphocytic leukemia $(C L L)^{1}$ has at least two distinct biochemical differences from normal B lymphocytes: altered cell surface glycoproteins $(1,2)$ and a profound decrease in $5^{\prime}$-nucleotidase activity $(3)$. A third abnormality that has been described recently is the lack of a 185,000-D cold insoluble globulin in CLL lymphocyte membranes, which is present in the membranes of normal B lymphocytes (4). It is not known whether the absence of this protein is the cause either of the decrease in membrane sialoproteins or the absence of 5 -nucleotidase activity. We have recently found that the plasma membranes of CLL B lymphocytes have a marked diminution of the L-system of amino acid transport when compared with blood $\mathrm{T}$ lymphocytes or with tonsillar lymphocytes (5).

By using lymphocytapheresis and differential cell separation techniques, we have been able to acquire sufficient numbers of human blood B lymphocytes for amino acid transport studies, and in this report we have been able to compare CLL B lymphocytes with normal human B lymphocytes. Further, we have applied a multicomponent computerized analysis to the calculation of amino acid transport so as to describe quantitatively

1. Abbreviations used in this paper: $\mathrm{BCH}, 2$-amino-2-carboxy-bicyclo $(2,2,1)$-heptane; CLL, chronic lymphocytic leukemia; $\nu_{i}$, initial velocity; methyl-AIB, methyl-amino-isobutyric acid. 
the carrier mediated and diffusional components of the L-system of transport in lymphocytes. These studies indicate that the $L$ system for amino acid transport is markedly diminished in CLL cells when compared either with blood B lymphocytes, tonsillar B lymphocytes, or with B lymphocyte lines derived from healthy donors.

\section{Methods}

Preparation of lymphocytes. Human blood T and B lymphocytes were prepared from the plateletpheresis residues of healthy blood donors (6). B lymphocytes were separated from the mixed cell populations using a nylon wool adherence technique (7). $24 \mathrm{~g}$ of nylon wool were packed in a $7 \times 6-\mathrm{cm}$ polypropylene column. The nylon wool was compacted to a volume of $240 \mathrm{ml}$ with a coarse (16 squares/in.) nylon mesh disc that fit snugly against the inside of the column. The column was heat sterilized and washed with $1,000 \mathrm{ml}$ of tissue culture medium (TC-199) containing $5 \%$ bovine calf serum at $37^{\circ} \mathrm{C} .8 \mathrm{ml}$ of a cell suspension that contained $3 \times 10^{8}$ lymphocytes $/ \mathrm{ml}$ was applied to the column and washed into the nylon wool with an additional $40 \mathrm{ml}$ of TC- 199 with $10 \%$ bovine calf serum. The column was sealed and incubated at $37^{\circ} \mathrm{C}$ for $45 \mathrm{~min}$ to allow adherence of the B lymphocytes. The nonadherent T lymphocytes were eluted from the column with $100 \mathrm{ml}$ TC-199 with $10 \%$ bovine calf serum. The column was washed with an additional $1,000 \mathrm{ml}$ of buffer. The adherent B lymphocytes were eluted by dispersing the nylon wool in $200 \mathrm{ml}$ of buffer and by decanting the suspended cells. This procedure resulted in the preparation of $1-2 \times 10^{8} \mathrm{~B}$ lymphocytes for amino acid transport studies.

Tonsillar lymphocytes were prepared by disruption of fresh tonsils and by step gradient separation of the cell suspension, as previously described (8). CLL B cells were obtained from the blood of patients with chronic leukemia who had stable disease and who had not received chemotherapy in the previous $6 \mathrm{mo}$. T lymphocytes were quantified by measurement of the proportion of E-rosette-forming cells, and B lymphocytes were identified by the presence of immunoglobulin on their surface using fluorescein-conjugated anti-Ig. The B lymphocyte line, RPMI 1788, derived from normal blood lymphocytes, is maintained in long-term culture in our laboratory. The cells were grown in McCoy's 5A medium with $10 \%$ fetal calf serum and were subcultured twice a week. The cells were removed from long-term culture and washed twice in Hank's buffered salt solution before resuspension and study.

Pathways for amino acid uptake. Mammalian cells have three major pathways for amino acid transport, the L-, A-, and ASC-systems (912). The L-system transports amino acids with rings or branches in their side chains such as leucine and phenylalanine, is transstimulated by intracellular L-system amino acids, and is insensitive to the sodium gradient across the plasma membrane. The synthetic amino acid, 2 amino-2-carboxy-bicyclo $(2,2,1)$-heptane $(\mathrm{BCH})$ is transported selectively by the L-system and is used to characterize this pathway (11). The A and ASC transport systems are dependent on the transmembrane sodium gradient. The A-system transports neutral amino acids with short, polar, or linear side chains, exhibits transinhibition, transports $N$-methylated amino acids, and can be characterized by the synthetic amino acid, methyl-amino-isobutyric acid (methyl-AIB), which is transported selectively by the A-system. The ASC-system transports alanine, serine, and cysteine, exhibits transstimulation, and does not transport $N$-methylated amino acids. There is no synthetic or natural occurring amino acid which is transported by the ASC-system alone.

Measurement of amino acid uptake. The initial velocity $\left(\nu_{\mathrm{i}}\right)$ of amino acid uptake was measured in Hank's buffered salt solution, $\mathrm{pH} 7.45$, which contained $1 \mathrm{~g} / \mathrm{dl}$ human albumin as previously described (9). In brief, the $\nu_{\mathrm{i}}$ was measured after $30 \mathrm{~min}$ of preincubation at $37^{\circ} \mathrm{C}$ to allow depletion of the internal amino acid pool. Uptake was initiated by adding $0.5 \mu \mathrm{Ci} / \mathrm{ml}$ of ${ }^{14} \mathrm{C}$-labeled amino acid with sufficient unlabeled carrier to provide amino acid concentrations from 0.1 to $4 \mathrm{mM}$. The samples were separated from the incubation media using a butylphthalate, corn oil gradient, and the $\nu_{i}$ was calculated from measurements of uptake made at $\mathbf{0 . 5} \mathrm{min}$ for leucine and $\mathrm{BCH}$ and at $1 \mathrm{~min}$ for methyl-AIB. No uptake of amino acids was observed at $4^{\circ} \mathrm{C}$. The $\nu_{\mathrm{i}}$ of amino acid transport was calculated from the formula: $\nu_{\mathrm{i}}=\mathrm{d}\left[\left(\mathrm{A}_{\mathrm{i}}\right) /\left(\mathrm{A}_{\mathrm{e}}\right)\right] / \mathrm{d} t \times \mathrm{C}_{\text {outside }}$, where $A_{i}$ and $A_{e}$ represent the intracellular and extracellular radioactivity. $\mathrm{C}_{\text {outside }}$ is the micromolar concentration of amino acid in incubation medium. $\nu_{\mathrm{i}}$ is expressed as micromoles per liter cell water per minute.

Calculation of the kinetics of amino acid uptake. A multicomponent analysis was used to analyze the kinetic parameters of amino acid uptake (10). The multicomponent analysis separates the rate of appearance of amino acid in lymphocytes into a saturable, carrier-mediated process that fits a Michaelis-Menten kinetic analysis and a passive diffusion process whose rate depends upon the diffusion constant and the difference in amino acid concentration across the plasma membrane. A computer program was used to calculate the best values for the $K_{\mathrm{m}}, \nu_{\max }$, and diffusion constant so as to minimize the sum of the squares of the residuals (S): $S=\Sigma\left\{\nu(n)-\left[\frac{\nu_{\max }}{\left(K_{\mathrm{m}} / \mathrm{C}_{\text {outside }}(n)\right)+1}+\mathrm{K}\left(\mathrm{C}_{\text {outside }}(n)\right.\right.\right.$ $\left.\left.\left.-\mathrm{C}_{\text {inside }}(n)\right)\right]\right\}^{2}$, where $S$ is the sum of the squared residuals; $\nu(n)$ is the measured velocity corresponding to $\mathrm{C}_{\text {outside }}(n)$; and $\mathrm{C}_{\text {outside }}(n)$ and $\mathrm{C}_{\text {inside }}(n)$ are the values for the $n^{\text {th }}$ external and internal amino acid concentrations, respectively. The derivation of this analysis has been published previously (10).

\section{Results}

L-System transport by CLL cells and other lymphocyte types. The initial rate of uptake of $0.1 \mathrm{mM}$ 2-amino-2-carboxy-bicyclo $(2,2,1)$-heptane is shown for CLL B lymphocytes, blood B lymphocytes, tonsillar B lymphocytes, a B cell line, RPMI 1788, and for T lymphocyte types in Table I. The CLL cells contained 94\% B lymphocytes; the blood B cells contained $75 \%$ B lymphocytes; the tonsillar B cells contained $61 \%$ B lymphocytes; the tonsillar cells contained $40 \%$ B and $34 \%$ T lymphocytes; and the blood $\mathrm{T}$ cells contained $70 \% \mathrm{~T}$ lymphocytes. $\mathrm{BCH}$ is a synthetic amino acid that is transported selectively by the $\mathrm{L}$ system of amino acid transport and can be used to characterize this system (11). The $\nu_{\mathrm{i}}$ for BCH in CLL lymphocytes, 57 $\mu \mathrm{mol} / \mathrm{l}$ cell water per min, was less than one-third that of separated blood B lymphocytes ( $189 \mu \mathrm{mol} / 1$ cell water per min), and $<20 \%$ the $\nu_{\mathrm{i}}$ of the other B and T cell types (Table I). These data suggest that the L-system of amino acid transport in CLL lymphocytes is markedly impaired when it is compared to other lymphocytes of either $\mathrm{T}$ or B cell origin.

These studies were conduced at a relatively low concentration of $\mathrm{BCH}, 0.1 \mathrm{mM}$, near the physiologic concentration of naturally occurring L-amino acids such as leucine. The diminished $L$ system transport in CLL lymphocytes observed at this relatively low concentration could reflect either a diminished substrate affinity of the amino acid transport protein and/or a diminished 
Table I. BCH Transport by B Cell CLL and Other B and T Lymphocytes

\begin{tabular}{llllll}
\hline & $\begin{array}{l}\text { B cell CLL } \\
\text { lymphocytes }\end{array}$ & $\begin{array}{l}\text { Blood-B } \\
\text { lymphocytes }\end{array}$ & $\begin{array}{l}\text { B cell } \\
\text { line }\end{array}$ & $\begin{array}{l}\text { Tonsillar-B } \\
\text { lymphocytes }\end{array}$ & $\begin{array}{l}\text { Tonsillar } \\
\text { lymphocytes } \\
\text { lymphocytes }\end{array}$ \\
\hline$\nu_{\mathrm{i}}$ & $57 \pm 15(8)$ & $189 \pm 20(7)$ & 455 & 393,435 & $317 \pm 28(3)$ \\
$\nu_{\max }$ & $81(6)$ & $1,029(6)$ & 900 & 878,805 & 841,702 \\
$K_{\mathrm{m}}$ & 92 & 555 & 53 & 154,107 & 138,106 \\
\hline
\end{tabular}

The $\nu_{\mathrm{i}}$ at $0.1 \mathrm{mM}$ and the $\nu_{\max }$ of amino acid transport are expressed as $\mu \mathrm{mol} / \mathrm{l}$ cell water per min, and the $K_{\mathrm{m}}$ as $\mu \mathrm{mol} / \mathrm{l}$. The mean $\pm \mathrm{SE}$ of the individual measurements is shown for the $\nu_{\mathrm{i}}$ at $0.1 \mathrm{mM}$. The $\nu_{\max }$ and $K_{\mathrm{m}}$ were calculated from the number of lymphocyte populations shown in parentheses. When fewer than three populations were studied, individual results are shown.

$\nu_{\max }$ of transport. We measured, therefore, the kinetics of $\mathrm{BCH}$ uptake as a measure of L-system transport in CLL lymphocytes. These data were analyzed with a computer-assisted program that permitted separation of the carrier-mediated uptake by the L-system from diffusion. Fig. 1 illustrates the analysis of $\mathrm{L}$ system transport in six populations of CLL lymphocytes. The observed data show that the $\nu_{\mathrm{i}}$ of $\mathrm{BCH}$ uptake did not reach a constant value with increasing $\mathrm{BCH}$ concentration. The multicomponent computerized analysis separated the rate of $\mathrm{BCH}$ uptake into a saturable uptake process and a passive diffusion

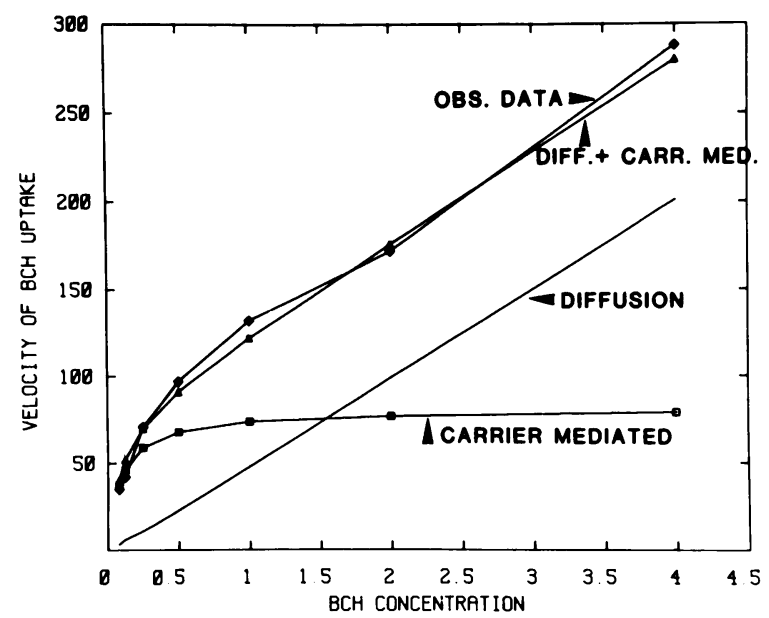

Figure 1. Multicomponent analysis of $\mathrm{BCH}$ uptake by CLL lymphocytes. The observed measurements of $\mathrm{BCH}$ uptake at $\mathrm{BCH}$ concentrations from 0.125 to $4.5 \mathrm{mM}$ are indicated by diamonds. The $\nu_{\mathrm{i}}$ of $\mathrm{BCH}$ uptake did not reach a constant value with increasing $\mathrm{BCH}$ concentration. This absence of saturation of the transport process resulted from the increased diffusion of $\mathrm{BCH}$ across the plasma membrane at increasing $\mathrm{BCH}$ concentrations. The multicomponent computerized analysis separated the rate of amino acid uptake into a carrier-mediated process, which obeys Michaelis-Menten kinetics and passive diffusion, which depends upon a diffusion constant and the difference in amino acid concentration across the plasma membrane The analysis produced a minimal residual value when the carrier-mediated transport and diffusion process were summed (triangles) and compared with the observed data. The carrier-mediated component of $\mathrm{BCH}$ uptake is indicated by squares and the rate of diffusion by the solid line. process. The analysis is designed to produce a minimal residual value when the carrier-mediated transport and the diffusion process are summed and compared with the experimental observations (Fig. 1).

The result of this analysis for BCH uptake in CLL lymphocytes is shown in Table II. The multicomponent analysis is compared with a direct analysis without consideration of diffusion. The computer analysis of the data indicated that a $\nu_{\max }$ for $\mathrm{BCH}$ was reduced by one-half from 160 to $80 \mu \mathrm{mol} / \mathrm{l}$ cell water per min, and the $K_{\mathrm{m}}$ for $\mathrm{BCH}$ reduced to $<30 \%$, from 320 to $90 \mu \mathrm{mol} / \mathrm{l}$, when compared with the observed data. The diffusion constant for $\mathrm{BCH}$ in CLL lymphocytes was $0.05 \mathrm{~min}^{-1}$.

Using this diffusion constant, we calculated the $\nu_{\max }$ and $\dot{K}_{\mathrm{m}}$ for $\mathrm{BCH}$ uptake in each individual population of CLL lymphocytes (Table III). The mean $K_{\mathrm{m}}$ in lymphocytes from CLL patients was $144 \pm 34 \mu \mathrm{mol} / \mathrm{l}$, and the $\nu_{\max }$ was $103 \pm 17 \mu \mathrm{mol} / 1$ cell water per min. These data, which include studies from four additional patients, are similar to those shown in Table II. Further, the lymphocytes from patient J.A. were studied on three occasions over a period of $1 \mathrm{yr}$. The $\nu_{\max }$ of $\mathrm{BCH}$ uptake was 57,50 , and $45 \mu \mathrm{mol} / \mathrm{l}$ cell water per min and the $K_{\mathrm{m}}$ was 156 , 98 , and $70 \mu \mathrm{mol} / \mathrm{l}$. Both pooled and individual $\mathrm{BCH}$ uptake data indicated a profound defect in L-system transport in CLL cells.

Using the multicomponent analysis of the observed data, the $\nu_{\max }$ of $\mathrm{BCH}$, i.e. L-system, transport was compared among CLL and other B and T cell types (Table I). The $\nu_{\max }$ of BCH uptake in CLL cells, $81 \mu \mathrm{mol} / 1$ cell water per min, was $<10 \%$ that measured in any of the other lymphocyte types. In particular,

Table II. Multicomponent Analysis of BCH Uptake by CLL Lymphocytes

\begin{tabular}{llll}
\hline & $\nu_{\max }$ & $K_{\mathrm{m}}$ & \multicolumn{1}{c}{ Diffusion } \\
\hline & $\begin{array}{l}\mu \mathrm{mol} / \mathrm{l} \text { cell } \\
\text { water/min }\end{array}$ & $\mu$ mol/l & $\mathrm{min}^{-1}$ \\
& 160 & 320 & - \\
Analysis of observed data & 80 & 90 & 0.05 \\
Computer analysis & 80 & &
\end{tabular}

The $\nu_{\max }$ of amino acid transport is expressed as $\mu \mathrm{mol} / \mathrm{l}$ cell water/ $\mathrm{min}$, and the $K_{\mathrm{m}}$ as $\mu \mathrm{mol} / \mathrm{l}$. Diffusion is expressed as $\mathrm{min}^{-1}$. 
Table III. BCH Kinetics in CLL Lymphocytes:

Individual Experiments

\begin{tabular}{lllll}
\hline Exp. no. & Patient & $\nu_{\max }$ & $K_{\mathrm{m}}$ & $\begin{array}{l}\text { Sheep red } \\
\text { cell rosettes }\end{array}$ \\
\hline & & $\begin{array}{l}\mu \text { mol/l cell } \\
\text { water/min }\end{array}$ & $\mu$ mol/l & $\%$ \\
1 & & 32 & 22 & 4 \\
2 & V.P. & 32 & 56 & 11 \\
3 & J.V. & 40 & 351 & - \\
4 & R.J. & 214 & 91 & - \\
5 & L.F. & 108 & 159 & 12 \\
6 & A.M. & 145 & 92 & 4 \\
7 & D.A. & 116 & 156 & 5 \\
8 & J.A. & 57 & 102 & 2 \\
9 & E.W. & 114 & 94 & 6 \\
10 & J.M. & 82 & 315 & 2 \\
Mean \pm SE & R.F. & 123 & $144 \pm 34$ & $5.8 \pm 1.4$ \\
\hline & & $103 \pm 17$ & &
\end{tabular}

The $K_{\mathrm{m}}$ and $\nu_{\max }$ were calculated in each experiment using a diffusion constant for BCH of $0.05 \mathrm{~min}^{-1}$, which was determined by computer analysis of data pooled from all observations (See Table II).

normal blood B lymphocytes, which should be the best homologue of CLL B lymphocytes; transported BCH at greater than 10 -fold the rate of CLL cells.

The affinity of the transport system $\left(K_{\mathrm{m}}\right)$ for $\mathrm{BCH}$ is shown also in Table I. The constants of B cell CLL, the B cell line, and blood $T$ lymphocytes were similar, and those of unseparated tonsillar cells and of tonsillar B cells were slightly higher. The $K_{\mathrm{m}}$ of blood B lymphocytes was more difficult to calculate, since limited cell availability resulted in fewer data points. However, the slower rate of $\mathrm{BCH}$ transport only at low $\mathrm{BCH}$ concentrations indicated that the $K_{\mathrm{m}}$ for blood B cells is higher than for the other lymphocyte types.

Transstimulation and L-system transport. The presence of L-system amino acids within the cell cytoplasm may accelerate the rate of L-system amino acid uptake by transstimulation (12). In order to minimize or eliminate transstimulation as a factor in the difference observed in CLL-lymphocyte L-system transport, we incubated all cells for $30 \mathrm{~min}$ in an amino acidfree medium before measurement of amino acid uptake. The preincubation should deplete the internal amino acid pool in each cell type studied. If amino acid depletion was incomplete at $30 \mathrm{~min}$ in normal lymphocytes, their uptake of L-system amino acids could be higher than CLL, in part as a result of transstimulation. We, therefore, incubated normal lymphocytes for $4 \mathrm{~h}$ in amino acid-free medium. Leucine uptake was $870 \pm 61$ $\mu \mathrm{mol} / \mathrm{l}$ cell water per min after $240 \mathrm{~min}$ with $0.5 \mathrm{mM}$ leucine continuously present in the incubation medium. The mean uptake of $0.5 \mathrm{mM}$ leucine in three lymphocyte populations incubated in the absence of external leucine was $868 \pm 127$ at 30 $\min , 950 \pm 200$ at $60 \mathrm{~min}$, and $770 \pm 200 \mu \mathrm{mol} / 1$ cell water per $\min$ at $240 \mathrm{~min}$.

To test further whether transstimulation influenced our measurements of L-system transport, BCH uptake in CLL lymphocytes preloaded with leucine was compared with uptake in cells depleted of amino acids. Parallel measurements of $\left[{ }^{14} \mathrm{C}\right]$ leucine uptake indicated a cell leucine concentration of $\sim 6 \mathrm{mmol} / \mathrm{l}$ cell water after $60 \mathrm{~min}$ exposure to $5 \mathrm{mM}$ leucine in the medium. BCH uptake at $0.1 \mathrm{mM}$ in the CLL cells from two patients was markedly impaired in both untreated ( 30 and $31 \mu \mathrm{mol} / \mathrm{l}$ cell water per min) and leucine-loaded ( 59 and 56 $\mu \mathrm{mol} / \mathrm{l}$ cell water per min) cells.

$B C H$ transport after $T$ cell depletion in CLL lymphocytes. The residual L-system transport in CLL lymphocytes was 10\% of that observed in normal blood B cells. This was approximately the proportion of $\mathrm{T}$ lymphocytes present in the CLL cell preparations, and thus the $T$ lymphocytes could account for all or part of the L-system transport in lymphocytes from CLL patients. In order to define the contribution of the $\mathrm{T}$ lymphocytes to the residual $\mathrm{BCH}$ uptake, we studied five additional CLL populations before and after removal of $\mathrm{T}$ cells. In Fig. 2, the $\nu_{\mathrm{i}}$ of $\mathrm{BCH}$ uptake at $\mathrm{BCH}$ concentrations from 0.125 to $1 \mathrm{mM}$ is shown for unseparated and T cell-depleted CLL lymphocytes. In these studies, the proportion of $\mathrm{T}$ lymphocytes was reduced from 5 to $0.5 \%$. There was no significant difference between the unseparated and T-depleted cells (Fig. 2).

In order to insure that we could detect a change in the rate

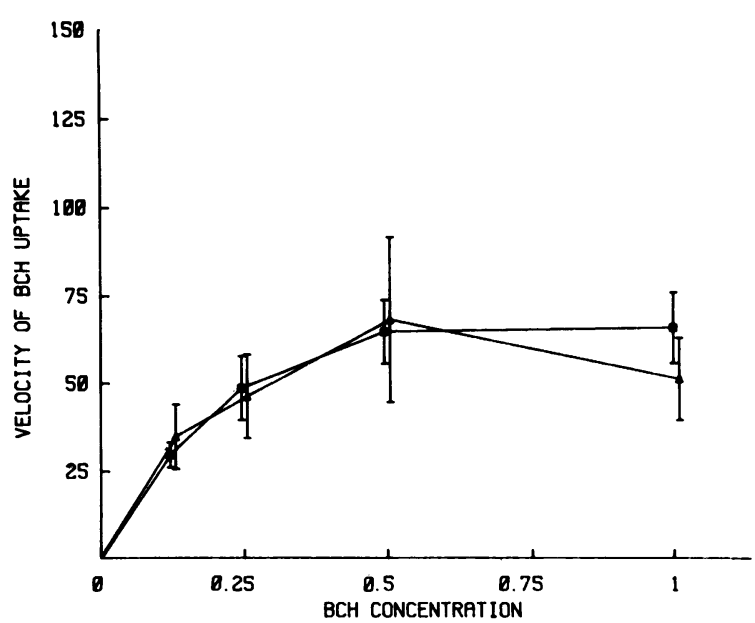

Figure 2. BCH uptake in unseparated and T cell-depleted CLL cells. The velocity of $\mathrm{BCH}$ uptake was measured at $\mathrm{BCH}$ concentrations between 0.125 and $1 \mathrm{mM}$. The $\nu_{\mathrm{i}}$ of $\mathrm{BCH}$ uptake in unseparated cells is indicated by the squares. The proportion of $T$ lymphocytes was reduced from 5 to $0.5 \%$ in each CLL cell population by rosetting the $T$ lymphocytes with neuraminidase-treated sheep erythrocytes and by separating the rosettes by step gradient centrifugation. The $\nu_{\mathrm{i}}$ of $\mathrm{BCH}$ uptake in T-depleted CLL lymphocytes is indicated by the triangles. The data represent the results from studies performed in five CLL lymphocyte populations. 
of $\mathrm{BCH}$ uptake in a CLL cell population before and after the removal of $5 \% \mathrm{~T}$ lymphocytes, the $\nu_{\max }$ of $\mathrm{BCH}$ transport was measured in three mixtures of CLL and normal blood lymphocytes (Table IV). In this study, we again observed a 10 -fold higher $\nu_{\max }$ for BCH uptake in normal blood lymphocytes as compared with CLL lymphocytes. Using these values, predicted uptakes for three mixtures were calculated. The observed uptakes were very similar to the predicted uptakes, and a mixture of 5\% normal blood lymphocytes and 95\% CLL lymphocytes was different from $100 \%$ CLL lymphocytes. This confirmed that the sensitivity of our uptake studies could detect a $5 \%$ decrement in $\mathrm{T}$ cells from a CLL population.

Leucine transport by CLL cells and other lymphocyte types. Leucine is an amino acid that is transported by the L-system in most cell types (12). The $\nu_{\mathrm{i}}$ for leucine in CLL lymphocytes, $193 \mu \mathrm{mol} / \mathrm{l}$ cell water per min, is less than one-half that of blood B lymphocytes, blood T lymphocytes, and tonsillar lymphocytes (Table V). The initial studies of leucine uptake were performed at a concentration of $0.1 \mathrm{mM}$. The diminished transport rate for leucine at this relatively low amino acid concentration was reflected also in the $\nu_{\max }$ of leucine uptake. The $\nu_{\max }, 450$ $\mu \mathrm{mol} / \mathrm{l}$ cell water per min, was approximately one-third that observed in blood B, blood $\mathrm{T}$ or tonsillar lymphocytes (Table V). The $K_{\mathrm{m}}$ for leucine in CLL cells, $208 \mu \mathrm{M}$, was slightly higher than that observed in tonsillar or blood $\mathrm{T}$ lymphocytes, but was lower than that measured in blood B lymphocytes $(459 \mu \mathrm{M})$. The higher $K_{\mathrm{m}}$ for leucine in blood B cells was in keeping with the higher $K_{\mathrm{m}}$ for $\mathrm{BCH}$, which indicates a lower carrier affinity for amino acids transported by the L-system in blood B cells. BCH transport in CLL B cells, however, indicated that leucine uptake should be $\sim 10 \%$ of normal B cells, whereas uptake was $\sim 35 \%$ of normal B cells. This finding suggested that leucine may be transported by an alternative uptake pathway (see below).

Competitive inhibition of leucine transport by unlabeled $\mathrm{BCH}$. $\left[{ }^{14} \mathrm{C}\right]$ leucine uptake was measured in the presence of $5 \mathrm{mM}$ $\mathrm{BCH}$ in order to define the proportion of leucine uptake mediated by the L-system. BCH blocked $70 \%$ of leucine uptake in blood T lymphocytes, 55\% in blood B lymphocytes, but blocked only $30 \%$ of leucine uptake in CLL lymphocytes (Table VI). BCH blocked its own uptake by $>80 \%$ in the three lymphocyte types. These data indicated a marked decrease in leucine transport

Table IV. $\nu_{\max }$ of BCH Transport in Mixtures of Blood and CLL Lymphocytes

\begin{tabular}{ccc}
\hline & Observed & Predicted \\
\hline 100\% Normal blood lymphocytes & 651 & - \\
$50 \%$ Normal + 50\% CLL & 334 & 356 \\
$25 \%$ Normal + 75\% CLL & 168 & 209 \\
$5 \%$ Normal + 95\% CLL & 91 & 91 \\
$100 \%$ CLL blood lymphocytes & 62 & - \\
\hline
\end{tabular}

The data are expressed as micromole per liter cell water per minute.
Table V. Leucine Transport by B Cell CLL and Other $B$ and $T$ Lymphocytes

\begin{tabular}{lllll}
\hline & $\begin{array}{l}\text { B Cell CLL } \\
\text { lymphocytes }\end{array}$ & $\begin{array}{l}\text { Blood B } \\
\text { lymphocytes }\end{array}$ & $\begin{array}{l}\text { Tonsillar } \\
\text { lymphocytes }\end{array}$ & $\begin{array}{l}\text { Blood T } \\
\text { lymphocytes }\end{array}$ \\
\hline $\begin{array}{llll}\nu_{\mathrm{i}} \text { at } 0.1 \mathrm{mM} \\
\nu_{\max }\end{array}$ & $\begin{array}{l}193 \pm 25(8) \\
K_{\mathrm{m}}\end{array}$ & $\begin{array}{l}393 \pm 47(4) \\
1,686(3)\end{array}$ & $\begin{array}{l}537 \pm 15(3) \\
1,430(3)\end{array}$ & $\begin{array}{l}492 \pm 44(7) \\
1,240(3) \\
118\end{array}$ \\
\hline
\end{tabular}

The $\nu_{\mathrm{i}}$ at $0.1 \mathrm{mM}$ and the $\nu_{\max }$ of amino acid transport are expressed as $\mu \mathrm{mol} / \mathrm{l}$ cell water/min, and the $K_{\mathrm{m}}$ as $\mu \mathrm{mol} / \mathrm{l}$. The mean $\pm \mathrm{SE}$ is shown for the $\nu_{\mathrm{i}}$ at $0.1 \mathrm{mM}$. The $\nu_{\max }$ and $K_{\mathrm{m}}$ were calculated from the number of lymphocyte populations shown in parentheses.

via the L-system in CLL lymphocytes. Since this finding implied that leucine is transported in CLL cells to a significant degree by a system other than the L-system, we examined the role of the ASC- and A-systems in leucine uptake.

Sodium dependence of leucine transport. Sodium-dependent leucine transport was calculated as the difference in the rate of leucine uptake at a sodium concentration of $140 \mathrm{mM}$ and at a sodium concentration of $10 \mathrm{mM}$. Since the internal concentration of sodium in human blood lymphocytes is $\sim 15 \mathrm{mM}$ (13), an external sodium concentration of $10 \mathrm{mM}$ eliminates the sodium gradient across the lymphocyte plasma membrane. Only $9.1 \%$ of leucine transport was sensitive to elimination of the sodium gradient in blood $\mathrm{T}$ lymphocytes, which is consistent with most of leucine uptake being mediated by the L-system which is sodium insensitive (Table VII). Sodium-sensitive leucine uptake was $20 \%$ in blood B lymphocytes and $43 \%$ in CLL lymphocytes (Table VII). These data quantify the proportion of leucine transport mediated by sodium-dependent amino acid transport systems, which include the A- and ASC-systems.

Methyl-AIB inhibition of leucine transport. Methyl-AIB is a synthetic amino acid that is transported selectively by the Asystem of amino acid transport and can be used to characterize the A-system (12). We determined which system played the principal role in leucine uptake by examining the methyl-AIB inhibition of leucine uptake; these experiments identified the

Table VI. Leucine Transport by CLL Lymphocytes: Percentage of Inhibition by Unlabeled $B C H$

\begin{tabular}{llll}
\hline $\begin{array}{l}\text { BCH } \\
\text { Inhibition of }\end{array}$ & $\begin{array}{l}\text { B Cell CLL } \\
\text { lymphocytes (8) }\end{array}$ & $\begin{array}{l}\text { Blood B } \\
\text { lymphocytes (3) }\end{array}$ & $\begin{array}{l}\text { Blood T } \\
\text { lymphocytes (4) }\end{array}$ \\
\hline$\left[{ }^{14} \mathrm{C}\right] \mathrm{BCH}$ & $84 \pm 2$ & 81,87 & $88 \pm 1$ \\
{$\left[{ }^{14} \mathrm{C}\right]$ Leucine } & $30 \pm 7$ & $55 \pm 3$ & $70 \pm 2$ \\
\hline
\end{tabular}

The data are expressed as the mean $\pm \mathrm{SE}$ of the percent inhibition. The $\nu_{\mathrm{i}}$ was measured at a ${ }^{14} \mathrm{C}$-amino acid concentration of $0.1 \mathrm{mM}$ and the unlabeled (inhibitory) amino acid was present at $5 \mathrm{mM}$. In the case of blood B lymphocytes, only two studies of $\mathrm{BCH}$ inhibition of $\left[{ }^{14} \mathrm{C}\right] \mathrm{BCH}$ uptake were performed. 
Table VII. Sodium Dependence of Leucine Transport

\begin{tabular}{ccll}
\hline & $\begin{array}{l}\text { B cell CLL } \\
\text { lymphocytes (3) }\end{array}$ & $\begin{array}{l}\text { Blood B } \\
\text { lymphocytes (3) }\end{array}$ & $\begin{array}{l}\text { Blood T } \\
\text { lymphocytes (8) }\end{array}$ \\
\hline $\mathrm{Na}_{0}=140 \mathrm{mM}$ & $233 \pm 12$ & $312 \pm 77$ & $601 \pm 55$ \\
$\mathrm{Na}_{0}=10 \mathrm{mM}$ & $133 \pm 11$ & $241 \pm 47$ & $549 \pm 56$ \\
Percent inhibition & $43 \pm 3$ & $20 \pm 4$ & $9.1 \pm 1.7$
\end{tabular}

The data are expressed as the mean $\pm \mathrm{SE}$ in $\mu \mathrm{mol} / \mathrm{l}$ cell water $/ \mathrm{min}$. The $v_{i}$ of amino acid uptake was measured at a concentration of 0.1 $\mathrm{mM}$

proportion of sodium-sensitive leucine uptake by the A-system. Inhibition of leucine uptake by methyl-AIB in five populations of CLL lymphocytes was only $11 \pm 5.1 \%$ (Table VIII). In these studies, methyl-AIB inhibited its own uptake by $>87 \%$ and $\mathrm{BCH}$ uptake by $<2 \%$, which was consistent with the specificity of methyl-AIB for the A-system of transport and $\mathrm{BCH}$ for the L-system.

Transport of phenylalanine by $C L L$, blood $B$, and $T$ lymphocytes. In order to explore the ability of CLL cells to transport a second naturally occurring L-system amino acid, phenylalanine uptake was quantified. Total phenylalanine uptake at $0.1 \mathrm{mM}$ was markedly diminished by CLL cells (40) when compared with normal lymphocytes ( $514 \mu \mathrm{mol} / 1$ cell water per min). Phenylalanine uptake, unlike that of leucine, has a large, nonsaturable component, so that our multicomponent analysis could not be applied to determine the kinetic parameters $\left(K_{\mathrm{m}}\right.$ and $\left.\nu_{\max }\right)$. In order to isolate the saturable components of uptake, we studied phenylalanine uptake in a normal and low sodium medium $(\sim 10 \mathrm{mM} \mathrm{NaCl})$ and in the presence and absence of a 50 -fold excess of $\mathrm{BCH}$. The low sodium medium eliminates the $\mathrm{A}$ and ASC components of uptake, and the $\mathrm{BCH}$-sensitive uptake defines the L-system component of phenylalanine transport. The $\nu_{\mathrm{i}}$ for the L-system component of phenylalanine uptake at $\mathbf{0 . 1}$ $\mathrm{mM}$ phenylalanine was $<10 \%$ of the uptake by blood B lymphocytes (Table IX). The $\nu_{\max }$ for the L-system component of phenylalanine uptake in CLL cells was 80 , compared with 800 $\mu \mathrm{mol} / \mathrm{l}$ cell water per min in blood B lymphocytes.

Table VIII. Leucine Transport in CLL Lymphocytes: Percentage of Inhibition by Unlabeled Methyl-AIB

\begin{tabular}{llll}
\hline $\begin{array}{l}\text { Methyl-AIB } \\
\text { inhibition of }\end{array}$ & $\begin{array}{l}\text { B cell CLL } \\
\text { lymphocytes (5) }\end{array}$ & $\begin{array}{l}\text { Blood B } \\
\text { lymphocytes (3) }\end{array}$ & $\begin{array}{l}\text { Blood T } \\
\text { lymphocytes (4) }\end{array}$ \\
\hline$\left[{ }^{14}\right.$ C]Methyl-AIB & $87 \pm 0.2$ & 88,79 & $88 \pm 1.2$ \\
{$\left[{ }^{14}\right.$ C]Leucine } & $11 \pm 5.1$ & 0 & $7.5 \pm 0.7$ \\
\hline
\end{tabular}

The data are expressed as the mean $\pm \mathrm{SE}$ of the percentage of inhibition. The $v_{i}$ was measured at a ${ }^{14} \mathrm{C}$-amino acid concentration of 0.1 $\mathrm{mM}$ and the unlabeled (inhibitory) amino acid was present at $5 \mathrm{mM}$. When fewer than three populations were studied, individual results are shown.
Table IX. L-System Transport of Phenylalanine by B Cell CLL and Blood B and T Lymphocytes

\begin{tabular}{clll}
\hline & $\begin{array}{l}\text { B-cell CLL } \\
\text { lymphocytes (3) }\end{array}$ & $\begin{array}{l}\text { Blood B } \\
\text { lymphocytes (2) }\end{array}$ & $\begin{array}{l}\text { Blood T } \\
\text { lymphocytes (3) }\end{array}$ \\
\hline$\nu_{\mathrm{i}}$ at $0.1 \mathrm{mM}$ for & & & \\
$\quad$ L-system & $21 \pm 2$ & 531,266 & $561 \pm 55$ \\
$\nu_{\max }$ for L-system & 80 & 822,796 & 636
\end{tabular}

These data represent the $\mathrm{BCH}$ inhibitable or L-system component of phenylalanine uptake. The $\nu_{\mathrm{i}}$ at $0.1 \mathrm{mM}$ and the $\nu_{\max }$ of amino acid transport, are expressed as $\mu \mathrm{mol} / 1$ cell water per min. The mean $\pm \mathrm{SE}$ is shown for the $\nu_{\mathrm{i}}$ at $0.1 \mathrm{mM}$. The $\nu_{\max }$ was calculated from the number of lymphocyte populations shown in parentheses.

Transport of methyl-AIB by CLL cells and other lymphocyte types. In contrast to the impaired L-system transport in CLL cells, A-system transport, as reflected by the uptake of methylAIB, was of greater magnitude in CLL cells than in blood B or $T$ lymphocytes (Table $X$ ). Unseparated tonsillar lymphocytes and tonsillar B cells showed a $\nu_{\mathrm{i}}$ at $0.1 \mathrm{mM}$ for methyl-AIB that was greater than other lymphocytes. The kinetic analysis of methyl-AIB uptake revealed a similar pattern of A-system transport in the five lymphocyte types studied (Table X). The $\nu_{\max }$ for methyl-AIB uptake was greater, $204 \mu \mathrm{mol} / 1$ cell water per $\mathrm{min}$, in CLL B lymphocytes than in isolated blood B lymphocytes (86 $\mu \mathrm{mol} / 1$ cell water per min) or in $\mathrm{T}$ lymphocytes (28 $\mu \mathrm{mol} / 1$ cell water per min). As was reflected in the $\nu_{\mathrm{i}}$ measured at $0.1 \mathrm{mM}$, the $\nu_{\max }$ for tonsillar B lymphocytes was higher than the other cell types. The $K_{\mathrm{m}}$ for methyl-AIB varied between 384 and $742 \mu \mathrm{M}$ in the various lymphocyte types (Table $\mathrm{X}$ ).

\section{Discussion}

We have expanded our preliminary observation that CLL B cells have a decreased capacity for L-system amino acid transport in two key ways. First, we have shown that the maximal capacity of L-system transport in CLL B cells is $\sim 10 \%$ of normal blood B cells, of tonsillar B cells, or of a B cell line. Second, we have isolated mathematically the carrier-mediated portion of L-system transport by the use of a multicomponent analysis, and, in so doing, have more accurately defined the kinetic parameters of L-system uptake. This latter analysis indicated that the residual rate of L-system transport ( $\sim 80 \mu \mathrm{mol} / 1$ cell water per min) in CLL populations could be explained by the $\mathrm{T}$ lymphocytes that are present in the CLL-cell preparations, if T cells in CLL patients are similar to normal blood T lymphocytes. A $10 \%$ fraction of $T$ cells in CLL patients' blood would contribute $\sim 100$ $\mu \mathrm{mol} / 1$ cell water per min (i.e. $0.1 \times \sim 1,000 \mu \mathrm{mol} / 1$ cell water per min) and would account for all of the $\mathrm{BCH}$ transport (i.e. L-system activity) observed in CLL patients' cells. However, analysis of L-system transport in CLL cell populations depleted of $T$ cells did not support this hypothesis. The removal of $T$ lymphocytes by E-rosetting and step gradient centrifugation did 
Table X. Methyl-AIB Transport by B Cell CLL and Other B and T Cell Types

\begin{tabular}{lllllc}
\hline & $\begin{array}{l}\text { B cell CLL } \\
\text { lymphocytes }\end{array}$ & $\begin{array}{l}\text { Blood B } \\
\text { lymphocytes }\end{array}$ & $\begin{array}{l}\text { Tonsillar B } \\
\text { lymphocytes }\end{array}$ & \multicolumn{1}{l}{$\begin{array}{l}\text { Tonsillar } \\
\text { lymphocytes }\end{array}$} & $\begin{array}{l}\text { Blood T } \\
\text { lymphocytes }\end{array}$ \\
\hline$\nu_{\mathrm{i}}$ at $0.1 \mathrm{mM}$ & $26 \pm 3.5(8)$ & $15 \pm 1.5(4)$ & 47 & $53 \pm 3(6)$ & $6.7 \pm 6(7)$ \\
$\nu_{\max }$ & $204(3)$ & $86(4)$ & 322 & $245(3)$ & $28(4)$ \\
$K_{\mathrm{m}}$ & 742 & 589 & 733 & 384 & 540 \\
\hline
\end{tabular}

The $\nu_{\mathrm{i}}$ at $0.1 \mathrm{mM}$ and the $\nu_{\max }$ of amino acid transport are expressed as $\mu \mathrm{mol} / \mathrm{l}$ cell water/min, and the $K_{\mathrm{m}}$ as $\mu \mathrm{mol} / \mathrm{l}$. The mean $\pm \mathrm{SE}$ of the individual measurements is shown for the $\nu_{\mathrm{i}}$ at $0.1 \mathrm{mM}$. The $\nu_{\max }$ and $K_{\mathrm{m}}$ were calculated from the pooled data from the number of lymphocyte populations shown in parentheses.

not significantly decrease $\mathrm{BCH}$ uptake. We were unable to measure directly the transport of T cells from CLL patients because adequate numbers of cells could not be isolated. This resulted from the low percentage of $\mathrm{T}$ lymphocytes, even in early stage CLL (14-16).

Leucine and phenylalanine transport by the L-system in CLL cells were markedly reduced to $<15 \%$ of other B lymphocyte types, which confirmed the very limited L-system transport, as judged by these naturally occurring amino acids. Unlike total phenylalanine uptake, total leucine uptake was considerably greater than predicted by the L-system capacity of CLL cells because of a "compensatory" shift in uptake to the ASC system. Although there is no specific, naturally occurring or synthetic amino acid to use in inhibition studies to identify the ASC system, the lack of significant methyl-AIB inhibition of leucine uptake, an argument against A-system uptake, and the substantial proportion of sodium-sensitive leucine uptake, strongly implies that the ASC-system is used for leucine uptake in CLL cells.

To our knowledge, this is the first description of a specific deficiency in a major amino acid transport system in a human neoplasm. Genetically defective A-system transport with a marked reduction in the $\nu_{\max }$ for aminoisobutyric acid has been described in a mutant lymphocyte cell line derived from the mouse (17). The residual A-system transport had a normal affinity for the amino acid, suggesting that the mutant cell line contained a defective regulatory gene, which resulted in the production of a diminished amount of normal protein.

There is precedent for altered protein composition of the lymphocyte plasma membrane in CLL lymphocytes. The cells from $70 \%$ of CLL patients show an absence of the enzyme 5'nucleotidase (3). Further, a decreased actin content, one of the major cytoskeletal proteins, has been described in B cell CLL and may be important in the defective capping of immunoglobulin observed in these cells (18). Recent studies have shown that CLL cells do not synthesize a 185,000-D cold insoluble globulin that is present in the plasma membrane of normal B lymphocytes (4). The relationship of the L-system transport protein to the 185,000 -D protein or to the decreased glycosylation (2) of other membrane proteins in CLL cells is not known.

The methyl-AIB, i.e. A-system, kinetics of transport in CLL cells and the compensatory increase in leucine uptake by the
ASC system indicate that there is not a general defect in amino acid transport, and argue against a metabolic impairment or nonspecific cell damage during cell separation affecting uptake. In addition, A-system transport in CLL cells has been extensively characterized. These studies have shown appropriate increases in A-amino acid transport after amino acid deprivation. This "adaptation" to an A-amino acid-deficient environment was dependent on de novo RNA and protein synthesis, which indicated functionality of the cells and of A-system regulation (19).

The defect in L-system amino acid transport in CLL appears to be a selective abnormality that is related to the neoplastic nature of this cell population. It is always difficult to be certain of the appropriate cells for comparison when studying distinctions in malignant cells from normal. Therefore, we have examined the L-system of a number of $\mathrm{T}$ and $\mathrm{B}$ lymphocyte types. Since the maximal velocities of $\mathrm{L}$-system transport of normal blood B lymphocytes, tonsillar B lymphocytes, and a B cell line were 10-fold that of the CLL cell preparations, it is likely that the transport rate in CLL cells represents an abnormality, rather than a reflection of B lymphocyte origin.

\section{Acknowledgments}

Marion Murphy, Elizabeth Kearney, and Geraldine Roberts gave expert technical assistance in these studies.

This work was supported by U. S. Public Health Service grants CA12970 and CA34691, by the Charles E. Culpeper Foundation, and by the University of Rochester Pediatric Blood Research "Jimmy Fund."

\section{References}

1. Kornfeld, S. 1969. Decreased phytohemagglutinin receptor sites in chronic lymphocytic leukemia. Biochim. Biophys. Acta. 192:542545.

2. Speckart, S. F., D. H. Boldt, and R. P. MacDermott. 1978. Chronic lymphatic leukemia (CLL): cell surface changes detected by lectin binding and their relation to altered glycosyl-transferase activity. Blood. 52:681695.

3. LaMantia, K., M. Conklyn, F. Quagliata, and R. Silber. 1977. Lymphocyte 5'-nucleotidase: absence of detectable protein in chronic lymphocytic leukemia. Blood. 50:683-689.

4. Simmonds, M. A., G. Sobczak, and S. P. Hauptman. 1982. Chronic 
lymphocytic leukemia cells lack the 185,000 -dalton macromolecular insoluble cold globulin present on normal B-lymphocytes. J. Clin. Invest. 67:624-631.

5. Segel, G. B., and M. A. Lichtman. 1982. Decreased L-system for amino acid transport in chronic lymphocytic leukemic lymphocytes. J. Biol. Chem. 257:9255-9257.

6. Segel, G. B., M. A. Lichtman, B. R. Gordon, J. L. MacPherson, and J. Nusbacher. 1976. Plateletpheresis residues: a source of large quantities of human blood lymphocytes. Transfusion. 16:455-459.

7. Handwerger, B. S., and R. H. Schwartz. 1974. Separation of murine lymphoid cells using nylon wool columns. Transplantation. 18:544-547.

8. Segel, G. B., and M. A. Lichtman. 1977. Decreased membrane potassium permeability and transport in human chronic leukemic and tonsillar lymphocytes. J. Cell. Physiol. 93:277-284.

9. Segel, G. B., and M. A. Lichtman. 1981. Amino acid transport in human lymphocytes: distinctions in the enhanced uptake with PHA treatment or amino acid deprivation. J. Cell. Physiol. 106:303-308.

10. Segel, G. B., W. Simon, and M. A. Lichtman. 1983. A multicomponent analysis of amino acid transport systems in human lymphocytes. 1. Kinetic parameters of the A and $L$ systems and pathways of uptake of natural occurring amino acids in blood lymphocytes. $J$. Cell. Physiol. 116:372-378.

11. Christensen, H. N., M. E. Handlogten, I. Lam, H. S. Tager, and R. Zand. 1969. A bicyclic amino acid to improve discriminations among transport systems. J. Biol. Chem. 244:1510-1520.
12. Guidotti, G. G., A. F. Borghetti, G. C. Gazzola. 1978. The regulation of amino acid transport in animal cells. Biochim. Biophys. Acta. 515:329-366.

13. Segel, G. B., W. Simon, and M. A. Lichtman. 1979. Regulation of sodium and potassium transport in phytohemagglutinin-stimulated human blood lymphocytes. J. Clin. Invest. 64:834-841.

14. Davis, S. 1976. The variable pattern of circulating lymphocyte subpopulations in chronic lymphocytic leukemia. N. Engl. J. Med. 294:1150-1153.

15. Smith, J. B., R. P. Knowlton, and L. S. Koons. 1977. Immunologic studies in chronic lymphocytic leukemia: Defective stimulation of Tcell proliferation in autologous mixed lymphocyte culture. J. Natl. Cancer Inst. 58:579-585.

16. Autio, K., O. Turunen, E. Eramaa, O. Penttila, and J. Schroder. 1979. Human chronic lymphocytic leukemia. Surface markers and activation of lymphocytes. Scand. J. Haematol. 23:265-271.

17. Dantzig, A. H., E. A. Adelberg, and C. W. Slayman. 1979. Properties of two mouse lymphocyte cell lines genetically defective in amino acid transport. J. Biol. Chem. 254:8988-8993.

18. Stark, R., L. F. Liebes, D. Nevrla, M. Conklyn, and R. Silber. 1982. Decreased actin content of lymphocytes from patients with chronic lymphocytic leukemia. Blood. 59:536-541.

19. Frengley, P. A., M. A. Lichtman, W. A. Peck. 1975. Adaptive enhancement of amino acid transport in human leukemic leukocytes: studies with alpha-aminoisobutyric acid. J. Lab. Clin. Med. 86:984996. 